\title{
Data report: Pleistocene diatoms from Sites U1302 and U1303, Orphan Knoll, northwestern Atlantic Ocean'
}

\author{
Oscar E. Romero²
}

\section{Chapter contents}

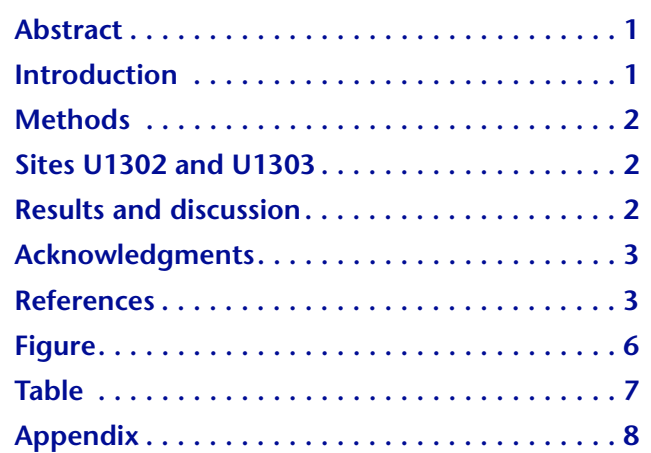

${ }^{1}$ Romero, O.E., 2008. Data report: Pleistocene diatoms from Sites U1302 and U1303, Orphan Knoll, northwestern Atlantic Ocean. In Channell, J.E.T., Kanamatsu, T., Sato, T., Stein, R., Alvarez Zarikian, C.A., Malone, M.J., and the Expedition 303/306 Scientists, Proc. IODP, 303/306: College Station, TX (Integrated Ocean Drilling Program Management International, Inc.).

doi:10.2204/iodp.proc.303306.203.2008

${ }^{2}$ Instituto Andaluz de Ciencias de la Tierra (IACTCSIC), Campus Fuentenueva, Facultad de Ciencias, Universidad de Granada, 18002 Granada, Spain. oromero@ugr.es

\section{Abstract}

Downcore variations of total diatom concentration and diatom assemblages have been studied along the upper 48 meters composite depth (mcd) of the corrected spliced composite section at Integrated Ocean Drilling Program Expedition 303 Sites U1302 and U1303. Diatom concentration varies between $1.0 \times 10^{3}$ and $2.1 \times 10^{6}$ valves/g. The highest diatom values are seen in the lower part, mostly between 35 and 48 mcd. The highly diversified diatom community is composed of $\sim 110$ species. The fossil diatom assemblage reflects the complex oceanographic setting in surface waters overlying Sites U1302 and U1303. Arctic/Subarctic components dominate the diatom assemblage, such as Actinocyclus curvatulus, Rhizosolenia hebetata var. hiemalis Bailey, Thalassiosira antiqua (Grunow) Cleve-Euler, Thalassiosira angulata, the vegetative cell of Thalassiosira gravida Cleve, and Thalassiosira trifulta G. Fryxell. Moderate influence of coastal waters is reflected by the occurrence of several species of resting spores of Chaetoceros, Actinocyclus octonarius Ehrenberg, Coscinodiscus radiatus Ehrenberg, and Thalassionema nitzschioides var. nitzschioides (Grunow) Van Heurck. Transport from shallow waters into the hemipelagic realm is mirrored by the presence of Delphineis karstenii (Boden) G. Fryxell and Paralia sulcata (Ehrenberg) Cleve, whereas Alveus marinus (Grunow) Kaczmarska and G. Fryxell and Fragilariopsis doliolus (Wallich) Medlin and Sims mainly represent a lowlatitude Atlantic signal.

\section{Introduction}

The Neogene-Quaternary diatom community of the north central and eastern Atlantic Ocean and the Nordic Seas is well known. Coring during Ocean Drilling Program Legs 151, 161, and 162 provided excellent recovery, allowing a detailed and reliable diatom biostratigraphy to be constructed for the Nordic Seas (Koç and Scherer, 1996; Koç and Flower, 1998; Koç et al., 1999) and the north central Atlantic (Baldauf, 1984, 1987). Less is known, however, about the preserved diatom communities from the high-latitude northwestern Atlantic Ocean. Because of its pelagic character, high rates of Pleistocene sedimentation, and the presence of a highly diversified diatom community (Shipboard Scientific Party, 2005) Sites U1302 and U1303 were chosen for a high-resolution study of the paleoclimatic and paleoceanographic changes that 
occurred in the high-latitude northwestern Atlantic during the last $1.5 \mathrm{~m} . \mathrm{y}$. This report presents the diatom concentration and lists the diatom species preserved in the upper 48 meters composite depth (mcd) of the corrected spliced composite section at Sites U1302 and U1303 near Orphan Knoll in the northwestern Atlantic, off Newfoundland.

\section{Methods}

For diatom study, we used $2 \mathrm{~cm}^{3}$ samples taken every $10 \mathrm{~cm}$. For light microscope study, samples were prepared following the method proposed by Schrader and Gersonde (1978). Qualitative and quantitative diatom analyses were done at $1000 \times$ magnification using a Zeiss-Axioscope with phase-contrast illumination. Counts were carried out on permanent slides of acid-cleaned material (Mountex mounting medium). Several traverses across the coverslip were examined, depending on valve abundance. At least two coverslips per sample were scanned in this way. Diatom counting of two replicate slides indicated that the analytical error of concentration estimates is $\leq 15 \%$. The counting procedure and definition of counting units for diatoms to the lowest possible taxonomic level followed those proposed by Schrader and Gersonde (1978).

\section{Sites U1302 and U1303}

Sites U1302 and U1303, separated by $5.68 \mathrm{~km}$ $\left(50^{\circ} 10^{\prime} \mathrm{N}, 48^{\circ} 38.3^{\prime} \mathrm{W}\right.$; water depth $\left.=\sim 3560 \mathrm{~m}\right)$, are located close to Orphan Knoll in the northwestern Atlantic, off Newfoundland. Drilling revealed a very similar stratigraphic sequence at both sites. An almost complete composite section was constructed at Site U1302 spanning the interval 0-107 mcd. The density and magnetic susceptibility records from Sites U1302 and U1303 are remarkably similar and can be easily correlated (Shipboard Scientific Party, 2005).

Sediments at Sites U1302 and U1303 are dominated by varying mixtures of terrigenous components and biogenic debris, primarily quartz, detrital carbonate, and nannofossils; therefore, the most common lithologies are clay, silty clay, silty clay with nannofossils, nannofossil silty clay, silty clay nannofossil ooze, and nannofossil ooze with silty clay (Shipboard Scientific Party, 2005). Dropstones are present throughout the cores. Samples from Sites U1302 and U1303 reveal rich assemblages of calcareous, siliceous, and organic-walled microfossils.

\section{Results and discussion}

Approximately 320 samples from the upper $48 \mathrm{mcd}$ of the corrected splice composite section at Sites U1302 and U1303 were studied. Following the North Atlantic diatom zonation proposed by Baldauf (1987), the event indicative of the change from the Fragilariopsis doliolus Zone (0-0.69 Ma) to the Fragilariopsis reinholdii Zone (0.69-1.88 Ma), which is the last occurrence of $F$. reinholdii, was not observed. $F$. reinholdii is present in a few samples, but because of the rarity of the specimens and sparsity of their occurrence biostratigraphically, these are thought to be reworked, which places the interval examined here entirely within the $F$. doliolus Zone (Baldauf, 1987) (Fig. F1).

Diatom concentration varies widely and ranges from $1.0 \times 10^{3}$ to $2.1 \times 10^{6}$ valves $/ g$ (average $=1.33 \times 10^{5}$ valves/g) (Table T1). The highest diatom concentration is recorded in the lower part, mostly between 35 and 48 mcd (Fig. F1). The moderate diatom concentration corresponds well with moderate to low biogenic silica (opal) content at Sites U1302 and U1303 (O. Romero, unpubl. data) and responds to the dominant mixture of terrigenous components (primarily quartz and detrital carbonate) and calcareous debris (Shipboard Scientific Party, 2005)

The diatom community is highly diversified (see the "Appendix"). We identified 110 species of diatoms in the upper 48 mcd of the corrected spliced composite section of Sites U1302 and U1303. On average, the most abundant diatoms are Thalassiosira angulata (Gregory) Hasle, Actinocyclus curvatulus Janisch and resting spores (RS) of Chaetoceros spp. (average relative contribution $=13.4 \%, 10.5 \%$, and $9.6 \%$, respectively).

The highly diversified diatom assemblage reflects the complex oceanographic setting of surface waters overlying Sites U1302 and U1303. The most abundant diatom group is the Arctic/Subarctic group, composed of A. curvatulus, Rhizosolenia hebetata var. hiemalis Bailey, Thalassiosira antiqua (Grunow) CleveEuler, T. angulata, the vegetative cell of Thalassiosira gravida Cleve, and Thalassiosira trifulta G. Fryxell (Andersen et al., 2004). The influence of coastal waters is reflected by the occurrence of several species of Chaetoceros RS, Actinocyclus octonarius Ehrenberg, Coscinodiscus radiatus Ehrenberg, and Thalassionema nitzschioides var. nitzschioides (Grunow) Van Heurck (Romero et al., 2003). Transport from coastal shallow waters into the hemipelagic realm is mirrored by Delphineis karstenii (Boden) G. Fryxell and Paralia sulcata (Ehrenberg) Cleve (Romero et al., 2003, 2008), whereas Alveus marinus (Grunow) Kaczmarska and G. 
Fryxell and F. doliolus (Wallich) Medlin and Sims mainly represent a tropical/subtropical signal (Romero et al., 2005). The qualitative and quantitative variations of the fossil diatom assemblage at Sites U1302 and U1303 will provide insight into paleoclimatologic and paleoceanographic Pleistocene variability in the high-latitude northwestern Atlantic.

\section{Acknowledgments}

I gratefully acknowledge the Shipboard Scientific Party and technical staff for their effort in collecting and sampling the sediments obtained during Expedition 303. Julianne Fenner is greatly acknowledged for her contributions in correcting and improving this report. Eva Kwoll helped with the sample preparation. I also thank the Integrated Ocean Drilling Program for providing the samples used in this study. Samples and/or data were provided by the Integrated Ocean Drilling Program (IODP). Funding for this research came from the Deutsche Forschungsgemeinschaft Project RO 3039/2-1.

\section{References}

Akiba, F., 1986. Middle Miocene to Quaternary diatom biostratigraphy in the Nankai trough and Japan Trench, and modified lower Miocene through Quaternary diatom zones for middle-to-high latitudes of the north Pacific. In Kagami, H., Karig, D.E., Coulbourn, W.T., et al., Init. Repts. DSDP, 87: Washington, DC (U.S. Govt. Printing Office), 393-481. doi:10.2973/ dsdp.proc.87.106.1986

Akiba, F., and Yanagisawa, Y., 1986. Taxonomy, morphology and phylogeny of the Neogene diatom zonal marker species in the middle-to-high latitudes of the North Pacific. In Kagami, H., Karig, D.E., Coulbourn, W.T., et al., Init. Repts. DSDP, 87: Washington, DC (U.S. Govt. Printing Office), 483-554. doi:10.2973/ dsdp.proc.87.107.1986

Andersen, C., Koç, N., and Moros, M., 2004. A highly unstable Holocene climate in the subpolar North Atlantic: evidence from diatoms. Quat. Sci. Rev., 23(2022):2155-2166. doi:10.1016/j.quascirev.2004.08.004

Andrews, G.W., and Rivera, P., 1987. Morphology and evolutionary significance of Adoneis pacifica gen. et. sp. nov. Diatom Res., 2:1-14.

Bailey, J.W., 1856. Notice of microscopic forms found in the soundings of the Sea of Kamtschatka. Am. J. Sci. Arts, 22(64):1-6.

Baldauf, J.G., 1984. Cenozoic diatom biostratigraphy and paleoceanography of the Rockall Plateau region, North Atlantic, Deep Sea Drilling Project Leg 81. In Roberts, D.G., Schnitker, D., et al. (Eds.), Init. Repts. DSDP, 81: Washington, DC (U.S. Govt. Printing Office), 439-478. doi:10.2973/dsdp.proc.81.107.1984
Baldauf, J.G., 1987. Diatom biostratigraphy of the middleand high-latitude North Atlantic Ocean, Deep Sea Drilling Project Leg 94. In Ruddiman, W.F., Kidd, R.B., Thomas, E., et al., Init. Repts. DSDP, 94: Washington, DC (U.S. Govt. Printing Office), 729-762. doi:10.2973/ dsdp.proc.94.115.1987

Boden, B.P., 1950. Some marine diatoms from the west coast of South Africa. Trans. R. Soc. S. Afr., 32:321-434.

Brightwell, T., 1858. Remarks on the genus "Rhizosolenia" of Ehrenberg. Q. J. Microsc. Sci., 6:93-95.

Cleve, P.T., 1873. On diatoms from the Arctic Sea. K. Sven. Vetenskapsakad. Handl., 1(13):1-28.

Cleve, P.T., and Grunow, A., 1880. Beiträge zur Kenntnis der arktischen Diatomeen. K. Sven. Vetenskapsakad. Handl., 17(2):1-121.

Cleve-Euler, A., 1952. Die Diatomeen von Schweden und Finnland. K. Sven. Vetenskapsakad. Handl., 3(5):1-153.

Crawford, R.M., 1979. Taxonomy and frustular structure of the marine centric diatom Paralia sulcata. J. Phycol, 15(2):200-210. doi:10.1111/j.0022-3646.1979.00200.x

Ehrenberg, C.G., 1838. Die Infusionsthierchen als vollkommene Organismen. Ein Blick in das tiefere organische Leben der Natur: Leipzig (Leopold Voss).

Ehrenberg, C.G., 1839a. Über die Bildung der Kreidefelsen und des Kreidemergels durch unsichtbare Organismen. Abh. K. Akad. Wiss. Berlin, 59-148.

Ehrenberg, C.G., 1839b. Über noch jetz zahlreich lebende Tierarten der Kreidebildung und den Organismus der Polythalamien. Abh. K. Akad. Wiss. Berlin, 81-174

Ehrenberg, C.G., 1844. Über 2 neue Lager von Gebirgsmassen aus Infusorien als Meeres-Absatz in Nord-Amerika und eine Vergleichung derselben mit den organischen Kreide-Gebilden in Europa und Afrika. Abh. K. Akad. Wiss. Berlin, 57-97.

Ehrenberg, C.G., 1845. Novorum generum et speciarum brevis definitio. Abh. Dtsch. Akad. Wiss. Berlin, 357-377.

Ehrenberg, C.G., 1854. Mikrogeologie: Das Erden und Felsen schaffende Wirken des unsichtbar kleinen selbständigen Lebens auf der Erde: Leipzig (Leopold Voss).

Fryxell, G.A., and Hasle, G.R., 1972. Thalassiosira eccentrica (Ehrenberg) Cleve, T. symmetrica sp. nov., and some related Centric diatoms. J. Phycol., 8:297-317. doi:10.1111/j.0022-3646.1972.00297.x

Fryxell, G.A., and Hasle, G.R., 1977. The genus Thalassiosira: some species with a modified ring of central strutted processes. Nova Hedwigia Beih., 54:67-98.

Fryxell, G.A., and Hasle, G.R., 1979. The genus Thalassiosira: T. trifuta sp. nova and other species with tricolumnar supports on strutted processes. Nova Hedwigia Beih., 64:13-31.

Fryxell, G.A., and Hasle, G.R., 1980. The marine diatom Thalassiosira oestrupii: structure, taxonomy and distribution. Am. J. Bot., 67(5):804-814. doi:10.2307/2442672

Fryxell, G.A., and Miller, W.I., III, 1978. Chain-forming diatoms: three araphid species. Bacillaria, 1:113-136.

Fryxell, G.A., Sims, P.A., and Watkins, T.P., 1986. Azpeitia (Bacillariophyceae): related genera and promorphology. Syst. Bot. Monogr., 13:1-74. 
Gasse, F., 1986. East African diatoms, taxonomy, ecological distribution. Bibl. Diatomol., 11:1-201.

Gregory, W., 1855. On a post-Tertiary lacustrine sand containing diatomaceous exuviae from Glenshira, near Inverness. Quat. J. Microscop. Sci., 3:30-43.

Gregory, W., 1857. On new forms of marine Diatomaceae found in the Firth of Clyde and in Loch Fyne. Trans. $R$. Soc. Edinburgh, 21:473-542.

Grunow, A., 1862. Die österreischischen Diatomaceen, nebst Anschluss einiger neuen Arten van andern Lokalitaten und einer kritischen Uebersicht der bishen bekannten Gattungen und Arten. Verh. Zool.-Bot. Ges. Wien, 12:315-472.

Grunow, A., 1881. Specimen florae cryptogamae septem insularum editum juxtaplantas Mazziarianas herbarii Heufleriani et speciatim quod filices herbarii Tommasiniani. Verh. Zool.-Bot. Ges. Wien, 412-430.

Grunow, A., 1884. Die diatomeen von Franz Josefs-Land. Denkschr. Kais. Akad. Wiss. Wien, Math.-Naturwiss. Kl., 48:53-112.

Hallegraeff, G.M., 1986. Taxonomy and morphology of the marine planktonic diatoms Thalassionema and Thalassiothrix. Diatom Res., 1:57-80.

Hargraves, P.E., and Schmid, A.M., 1992. Morphology, cytology, and growth characteristics of the diatom Planktoniella sol (Wall.) Schütt. Proc. $11^{\text {th }}$ Diatom Symp., 11:221-234.

Harwood, D.M., 1989. Siliceous microfossils. In Barrett, P.J. (Ed.), Antarctic Cenozoic History from the CIROS-1 Drillhole, McMurdo Sound. DSIR Bull. (N. Z.), 245:67-97.

Hasle, G.R., 1965. Nitzschia and Fragilariopsis species in the light and electron microscopes. III. The genus Fragilariopsis. Skr. Nor. Vidensk.-Akad. Kl. 1: Mat.-Naturvidensk Kl., 21:5-49.

Hasle, G.R., 1972. The inclusion of Coscinoscira Gran (Bacillariophyceae) in Thalassiosira Cleve. Taxon, 21(4):543-544. doi:10.2307/1219143

Hasle, G.R., and Fryxell, G.A., 1977. The genus Thalassiosira: some species with a linear areola array. Nova Hedwigia Beih., 54:15-66.

Hasle, G.R., and Sims, P.A., 1986. The diatom genus Coscindiscus Ehrenb.: C. argus Ehrenb. and C. radiatus Ehrenb. Bot. Mar., 29:305-318.

Hasle, G.R., and Syvertsen, E.E., 1996. Marine diatoms. In Tomas, C.R. (Ed.), Identifying Marine Diatoms and Dinoflagellates: New York (Academic Press), 5-386.

Hendey, N.I., 1958. Marine diatoms from some west African ports. J. R. Microsc. Soc., 77(1-2):28-85.

Hendey, N. I., 1964. An introductory account of the smaller algae of British coastal waters. V: Bacillariophyceae (diatoms). Minist. Agric., Fish. Food, Fish. Invest., Ser. IV.

Heiden, H., and Kolbe, R.W., 1928. Die marinen Diatomeen der Deutschen Südpolar-Expedition 19011903. In von Drygalski, E. (Ed.), Deutsche Südpolar-Expedition, 1901-1903 (Vol. 8): Botanik: Berlin (Walter de Gruyter), 447-715.

Hustedt, F., 1927-1966. Die Kieselalgen Deutschlands, Osterreichs und der Schweiz, mit Berücksichtigung der übrigen Länder Europas sowie der angrenzenden Meeresgebiete. In Rabenhorst, L. (Ed.), KryptogamenFlora von Deutschland. Oesterreich und der Schweiz: Leipzig (Akademische Verlagsgesellschaft), Teil I, Sect. 1-4, 1920.

Jousé, A.P., 1959. The main phases in the development of the flora of marine diatoms in the far eastern seas of the U.S.S.R. at the end of the Tertiary, and during the Quaternary period. Bot. Zh., 44:44-55.

Jousé, A.P., 1968. New species of diatoms in bottom sediment of the Pacific and the Sea of Okhotsk. Nov., Sist. Nizshikh Rast., 3:12-21.

Kaczmarska, I., and Fryxell, G.A., 1996. Alveus, gen. nov. (Bacillariaceae, Bacillariophyta), a heavily silicified diatom found in warm water oceans. Microsc. Res. Tech., 33(1):2-11. doi:10.1002/(SICI)1097-

0029(199601)33:1<2::AID-JEMT2>3.0.CO;2-X

Karsten, G., 1907. Das Indische phytoplankton. Deutschen Tiefsee Expedition 1889-1899, 2:221-538.

Koç, N., and Flower, B.P., 1998. High-resolution Pleistocene diatom biostratigraphy and paleoceanography of Site 919 from the Irminger Basin. In Saunders, A.D., Larsen, H.C., and Wise, S.W., Jr. (Eds.), Proc. ODP, Sci. Results, 152: College Station, TX (Ocean Drilling Program), 209-219. doi:10.2973/ odp.proc.sr.152.218.1998

Koç, N., Hodell, D.A., Kleiven, H., and Labeyrie, L., 1999. High-resolution Pleistocene diatom biostratigraphy of Site 983 and correlations with isotope stratigraphy. In Raymo, M.E., Jansen, E., Blum, P., and Herbert, T.D. (Eds.), 1999. Proc. ODP, Sci. Results, 162: College Station, TX (Ocean Drilling Program), 51-62. doi:10.2973/ odp.proc.sr.162.035.1999

Koç, N., and Scherer, R.P., 1996. Neogene diatom biostratigraphy of the Iceland Sea Site 907. In Thiede, J., Myhre, A.M., Firth, J.V., Johnson, G.L., and Ruddiman, W.F. (Eds.), Proc. ODP, Sci. Results, 151: College Station, TX (Ocean Drilling Program), 61-74. doi:10.2973/ odp.proc.sr.151.108.1996

Le Cohu, R., 1996. Further observations and some comments on the fine structure of the centric diatom Aulacoseira islandica (Bacillariophyceae). J. Phycol., 32(2):333-338.

Lyngbye, H.C., 1819. Tentamen Hydrophytologiae Danicae, Hafniae: in Commissis Librariae Gyldendaliae.

Medlin, L.K., and Sims, P.A., 1993. The transfer of Pseudoeunotia doliolus to Fragilariopsis. Nova Hedwigia Beih., 106:323-334.

Müller, O., 1906. Pleomorphismus, Auxosporen und Dauersporen bei Melosira-Arten. Jahrb. Wiss. Bot., 43:49-88.

Ostenfeld, C.H., 1900. Plankton in 1899. In Knudsen, M., Ostenfeld, C.H., (Eds.), Iagttagelser over Overfladevandets Temperatur, Saltholdighet og Plankton paa Islndske of Grønlandske Skibsrouter i 1899, 43-93.

Peragallo, H., 1892. Monographie du genre Rhizosolenia et de quelques genres voisins. Le Diatom., 1:79-82, 99-117.

Rines, J.E.B., and Hargraves, P.E., 1988. The Chaetoceros Ehrenberg (Bacillariophyceae) flora of Narrangansett Bay, Rhode Island, U.S.A. Bibl. Diatomol., 79:1-196. 
Romero, O.E., Armand, L.K., Crosta, X., and Pichon, J.-J., 2005. The biogeography of major diatom taxa in Southern Ocean surface sediments: 3. Tropical/Subtropical species. Palaeogeog., Palaeoclimatol., Palaeoecol., 223(12):49-65. doi:10.1016/j.palaeo.2005.03.027

Romero, O.E., Kim, J.-H., and Donner, B., 2008. Submillennial-to-millennial variability of diatom production off Mauritania, NW Africa, during the last glacial cycle. Paleoceanography, 23(3):PA3218. doi:10.1029/ 2008PA001601

Romero, O.E., Mollenhauer, G., Schneider, R.R., and Wefer, G., 2003. Oscillations of the siliceous imprint in the central Benguela Upwelling System from MIS 3 through to the early Holocene: the influence of the Southern Ocean. J. Quatenary Sci., 18(8):733-743. doi:10.1002/ jqs.789

Romero, O.E., and Rivera, P., 1996. Morphology and taxonomy of three varieties of Cocconeis costata and C. pinnata (Bacillariophyceae) with considerations of Pleuroneis. Diatom Res., 11(2):317-343.

Roper, F.C.S., 1858. Notes on some new species and varieties of British marine diatomaceae. Q. J. Microsc. Soc., 6:17-25.

Round, F.E., Crawford, R.M., and Mann, D.G., 1990. The Diatoms: Biology and Morphology of the Genera: Cambridge (Cambridge Univ. Press).

Sancetta, C., 1987. Three species of Coscinodiscus Ehrenberg from North Pacific sediments examined in the light and scanning electron microscopes. Micropaleontology, 33:230-241. doi:10.2307/1485639

Schmidt, A., von Schmidt, M., Fricke, F., Heiden, H., Müller, O., and Hustedt, F., 1874-1959. Atlas der Diatomaceenkunde: Leipzig (O.R. Reisland).

Schrader, H.J., and Gersonde, R., 1978. Diatoms and silicoflagellates. In Zachariasse, W.J., et al. (Eds.), Micropaleontological Counting Methods and Techniques: An Exercise of an Eight Metres Section of the Lower Pliocene of Cap Rossello, Sicily. Utrecht Micropaleontol. Bull., 17:129-176.
Shipboard Scientific Party, 2005. North Atlantic climate: ice sheet-ocean atmosphere interactions on millennial timescales during the late Neogene-Quaternary using a paleointensity-assisted chronology for the North Atlantic. IODP Prel. Rept., 303. doi:10.2204/

iodp.pr.303.2005

Shiono, M., 2000. Three new species in the Thalassiosira trifulta group in late Neogene sediments from the northwest Pacific Ocean. Diatom Res., 15:131-148.

Simonsen, R., 1974. The diatom plankton of the Indian Ocean expedition of R/V Meteor, 1964-1965. "Meteor" Forschunsergeb., Reihe D, 19:1-107.

Smith, W., 1953. A Synopsis of the British Diatomaceae: with Remarks on Their Structure, Functions and Distribution; and Instructions for Collecting and Preserving Specimens (Vol. 1): London (Van Hoorst).

Sundström, B.G., 1986. The marine diatom genus Rhizosolenia: a new approach to the taxonomy [Ph.D. dissert.]. Univ. Gothorum Carolinae, Sweden.

Syvertsen, E.E., 1977. Thalassiosira rotula and T. gravida: ecology and morphology. Nova Hedwigia Beih., 54:99-112.

Van Heurck, H., 1880-1885. Synopsis des Diatomées de Belgique. Atlas (1880-1881), Texte (1885). Anvers (Van Hoorst).

VanLandingham, S.L., 1968. Catalogue of the Fossil and Recent Genera and Species of Diatoms and their Synonyms: Part II. Bacteriastrum through Coscinodiscus: Lehrte (Verlag J. Cramer).

Wallich, G.C., 1860. On the siliceous organisms found in the digestive cavities of the Salpae, and their relation to the flint nodules of the Chalk Formation. Trans. Microsc. Soc. London, 8:36-55.

Initial receipt: 7 May 2008

Acceptance: 6 September 2008

Publication: 31 March 2009

MS 303306-203 
Figure F1. Total diatom concentration, Sites U1302 and U1303. Biostratigraphy mainly from Baldauf (1987). For comparison, the diatom zonation proposed by Koç and Flower (1998) for the North Atlantic north of $60^{\circ} \mathrm{N}$ is shown.

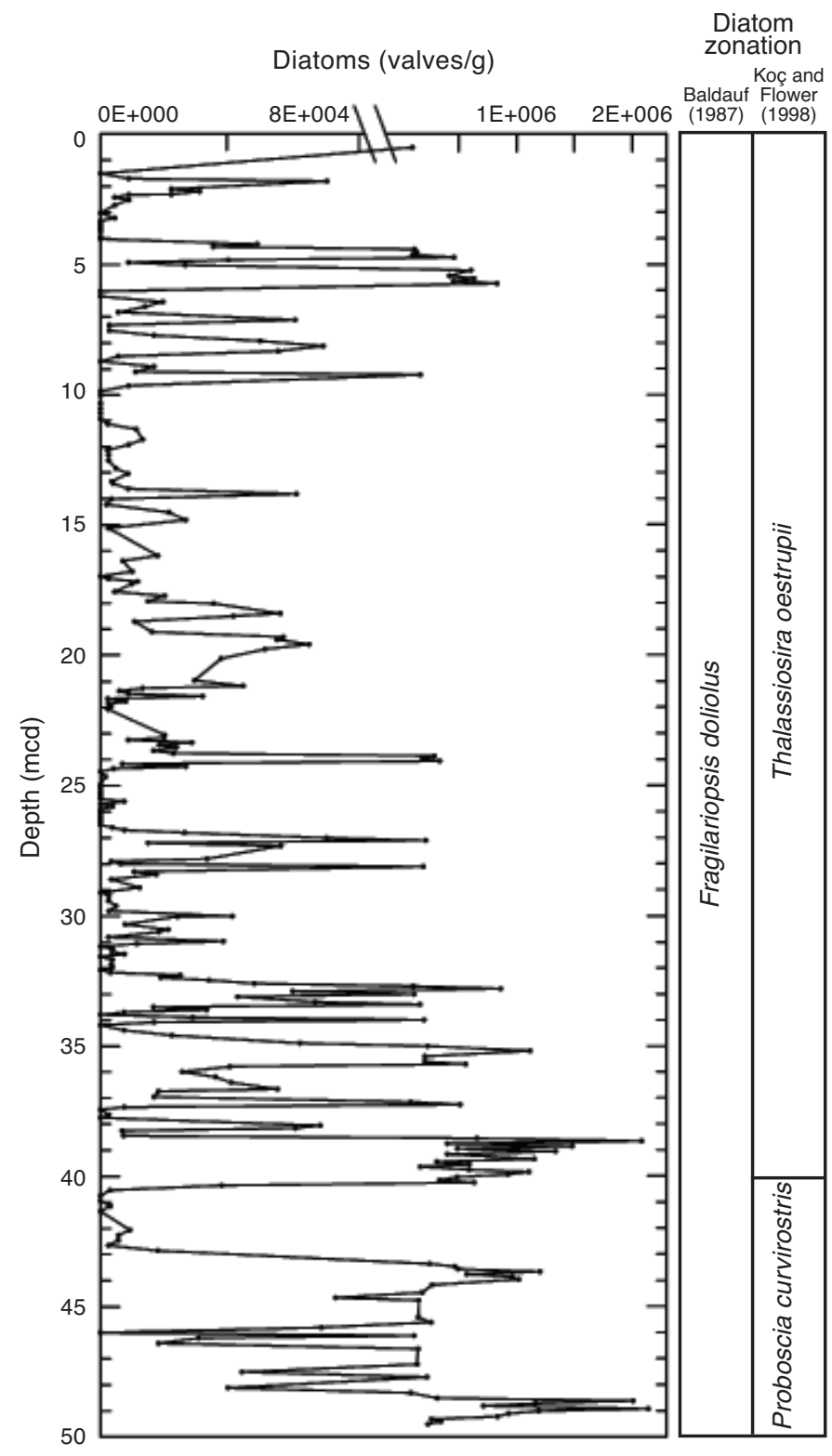


Table T1. Relative contribution of diatoms, Sites U1302 and U1303. This table is available in an oversized format. 


\section{Appendix \\ Species list}

The following list presents all the species and varieties of diatoms (Bacillariophyta) identified in the upper $48 \mathrm{mcd}$ of the corrected spliced composite section of Sites U1302 and U1303 at the Orphan Knoll in the northwestern Atlantic Ocean. Almost all of species were identified to the lowest possible taxonomic level. For each taxon identified at species level, the author's name, date of the original publication, and published figures are quoted, followed by the work used for its identification in this report.

Actinocyclus curvatulus Janisch

Janisch (in Schmidt et al., 1874-1959), pl. 57, fig. 31

Hustedt (1927-1966), p. 538, fig. 307

Actinocyclus elongatus Grunow

Grunow (1881), pl. 3, fig. 14

Simonsen (1974), p. 21, pl. 20, figs. 1-3

Actinocyclus octonarius Ehrenberg

Ehrenberg (1838), pl. 3, fig. 14

Hustedt (1927-1966), p. 524, fig. 298

Actinoptychus senarius (Ehrenberg) Ehrenberg

Ehrenberg (1838), p. 172, pl. 21, fig. 6

Hasle and Syvertsen (1996), p. 141, pl. 22

Adoneis pacifica G.W. Andrews and P. Rivera

Andrews and Rivera (1987), pp. 1-14

Alveus marinus (Grunow) Kaczmarska and G. Fryxell Cleve and Grunow (1880), p. 70

Kaczmarska and Fryxell (1996), p. 2, figs. 1-35

Aulacoseira granulata (Ehrenberg) Ralfs in Pritchard Ehrenberg (1839b), p. 415

Hustedt (1927-1966), p. 248, fig. 104

Aulacoseira islandica (O. Müller) Simonsen O. Müller (1906), p. 56, pl. 1/(3-), fig. 6 Le Cohu (1996), p. 333, figs. 1-19

Azpeitia neocrenulata (VanLandingham) G. Fryxell and T.P. Watkins

VanLandingham (1968), p. 930

Fryxell et al. (1986), p. 18, figs. 16, 30-2

Azpeitia tabularis (Grunow) G. Fryxell and T.P. Watkins

Schmidt et al. (1874-1959), pl. 59, figs. 20, 22, 23

Fryxell et al. (1986), p. 19, figs. 17, 18-1, 18-5, 30-3, $30-4$

Chaetoceros bacteriastroides Karsten

Karsten (1907), p. 390, pl. 44, figs. 2a-2c

Resting spores of Chaetoceros (Chaetoceros affinis, Chaetoceros compresus, Chaetoceros diadema, Chaetoceros debilis, and Chaetoceros sp. (unidentified)

Rines and Hargraves (1988), pp. 1-196

Cocconeis costata var. costata Gregory

Gregory (1855), p. 39, pl. 4, fig. 10
Romero and Rivera (1996), p. 321, figs. 2-16

Coscinodiscus argus Ehrenberg

Ehrenberg (1839a), p. 129

Hasle and Sims (1986), p. 308, figs. 1-7, 33, 34

Coscinodiscus decrescens Grunow

Grunow (in Schmidt et al., 1874-1959), pl. 61, figs. 7-9

Hendey (1964), p. 77

Coscinodiscus marginatus Ehrenberg

Ehrenberg (1844), p. 78

Hasle and Syvertsen (1996), p. 107, pl. 18

Coscinodiscus oculus-iridis Ehrenberg

Ehrenberg (1854), pl. 19, fig. 2

Sancetta (1987), p. 235, pl. 2, figs. 11-14; pl. 3

Coscinodiscus radiatus Ehrenberg

Ehrenberg (1839b), pl. 3, fig. 1

Hasle and Sims (1986), p. 310, figs. 8-32, 35-39

Cymatosira sp.

Cymbella sp.

Delphineis karstenii (Boden) G. Fryxell

Boden (1950), p. 406, fig. 87

Fryxell and Miller (1978), p. 116, figs. 1-10

Diploneis sp.

Eunotia sp.

Fallacia nyella (Hustedt ex Simonsen) D.G. Mann Hustedt (1927-1966), p. 535, fig. 1571

Fragilariopsis doliolus (Wallich) Medlin and Sims Wallich (1860), p. 48, pl. 2, fig. 19

Hasle and Syvertsen (1996), p. 303, pl. 69

Fragilariopsis fossilis (Frenguelli) Medlin and P.A. Sims Frenguelli (1949), p. 118, pl. 1, fig. 7

Medlin and Sims (1993), p. 332

Fragilariopsis oceanica (Cleve) Hasle

Cleve (1873), p. 22, pl. 4

Hasle (1965), p. 11, pl. 1, figs. 15-19; pl. 2, figs. 6, 7

Fragilariforma sp.

Gomphonema sp.

Grammatophora sp.

Hemidiscus cuneiformis Wallich Wallich (1860), p. 42, pl. 2, figs. 3, 4 Fryxell et al. (1986), p. 25, fig. XXVI

Lioloma sp.

Navicula distans (Wm. Smith) Ralfs in Pritchard Smith (1853), p. 56, pl. 18, fig. 169

Hendey (1964), p. 203, pl. 17, fig. 13

Nitzschia interruptestriata (Heiden) Simonsen

Heiden and Kolbe (1928), p. 665, pl. 7, fig. 150

Simonsen (1974), p. 52, pl. 36, figs. 9-11; pl. 37; pl. 38, figs. 1-7

Nitzschia sp. 
Odontella aurita (Lyngbye) C.A. Agardh Lyngbye, 1819 , p. 182 , pl. 62 Hasle and Syvertsen (1996), p. 236, pl. 49

Paralia sulcata (Ehrenberg) Cleve Ehrenberg (1838), p. 170, pl. 21, fig. 5 Crawford (1979), p. 201, figs. 1-33

Pinnularia sp.

Planktoniella sol (Wallich) Schütt Wallich (1860), p. 38, pl. 2, fig. 1 Hargraves and Schmid (1992), p. 222, pl. 1, figs. 1-6; pl.

2 , figs. 7-18

Porosira glacialis (Grunow) Jørgensen Grunow (1884), p. 108, pl. 5, fig. 32 Hasle and Syvertsen (1996), p. 236, pl. 49

Proboscia alata (Brightwell) Sundström Brightwell (1858), p. 95, pl. 5, fig. 8 Sundström (1986), p. 99, figs. 258-266

Proboscia curvirostris Jousé Jousé, 1959, p. 48, pl. 2, fig. 17; Akiba and Yanagisawa (1986), p. 497, pl. 42, figs. 1, 2; pl. 45, figs. $1-6$

Psammodyction panduriforme (Gregory) D.G. Mann Gregory (1857), p. 80, pl. 1, fig. 45 Mann (in Round et al., 1990), p. 612, figs. a-i

Rhizosolenia acuminata (H. Peragallo) H. Peragallo in H. and M. Peragallo Peragallo (1892), p. 110, pl. 2, fig. 4 Sundström (1986), p. 69, figs. 31, 165-176

Rhizosolenia bergonii $\mathrm{H}$. Peragallo Peragallo (1892), p. 110, pl. 2, fig. 5 Sundström (1986), p. 72, figs. 32, 33, 177-189

Rhizosolenia borealis Sundström Sundström (1986), p. 30, figs. 10, 11, 80-87

Rhizosolenia hebetata f. hiemalis Bailey Bailey (1856), p. 5, pl. 1, figs. 18, 19 Hasle and Syvertsen (1996), p. 149, pl. 27

Roperia tesselata (Roper) Grunow Roper (1858), p. 19, pl. 3, fig. 1 Fryxell et al. (1986), p. 24, figs. XXV, XXXII-3, 4

Stephanodiscus astraea (Ehrenberg) Grunow Ehrenberg (1845), p. 267 Gasse (1986), p. 167, pl. V, figs. 1, 2

Stephanopyxis grunowii Grove and Stuart Grove and Stuart (in Schmidt et al., 1874-1959), pl. 130, figs. $1-5$ Harwood (1989), p. 81, pl. 2, figs. 1-4

Thalassionema nitzschioides var. nitzschioides (Grunow) Van Heurck

Grunow (1862), p. 403, pl. 5, fig. 18 Hallegraeff (1986), p. 58, figs. 1-4

Thalassiosira angulata (Gregory) Hasle
Gregory (1857), p. 498, pl. 10, fig. 43

Hasle and Syvertsen (1996), p. 51, pl. 4

Thalassiosira antiqua (Grunow) Cleve-Euler Cleve-Euler (1952), p. 72, fig. 119

Akiba (1986), p. 445, pl. 12, figs. 1, 3, 4

Thalassiosira bipora Shiono 2000

Shiono (2000), p. 139, figs. 25-44

Thalassiosira eccentrica (Ehrenberg) Cleve

Ehrenberg (1839b), p. 146

Fryxell and Hasle (1972), p. 300, figs. 1-18

Thalassiosira ferelineata Hasle and G. Fryxell

Hasle and Fryxell (1977), p. 26, figs. 46-53

Thalassiosira gravida Cleve (vegetative cell) Cleve (1886), p. 12, pl. 2, figs. 14-16

Syvertsen (1977), p. 102, pl. 1, figs. 3, 4; pl. 3, fig. 13

Thalassiosira gravida (spore) Syvertsen (1977), p. 102, pl. 4

Thalassiosira grunowii (Grunow in Schmidt et al.) F. Akiba and Y. Yanagisawa

Grunow (in Schmidt et al., 1874-1959), p. 59, fig. 1

Akiba and Yanagisawa (1986), p. 493, pl. 27, fig. 5; pl.

29, figs. $1-8 b$; pl. 30, figs. $1-10$

Thalassiosira jouseae F. Akiba

Akiba (1986), p. 457, pl. 6, figs. 8-10

Thalassiosira leptopus (Grunow) Hasle and G. Fryxell Grunow (in Van Heurck, 1883), pl. 131, figs. 5, 6 Hasle and Fryxell (1977), p. 20, figs. 1-14

Thalassiosira lineata Josué Josué (1968), p. 13, pl. 1, figs. 1, 2 Hasle and Fryxell (1977), p. 22, figs. 15-25

Thalassiosira nodulolineata (Hendey) Hasle and G. Fryxell Hendey (1958) p. 39, pl. 5, figs. 4, 5 Hasle and Fryxell (1977), p. 35, figs. 86-93

Thalassiosira oestrupii var. oestrupii (Ostenfeld) Hasle Ostenfeld (1900), p. 52

Hasle (1972), p. 544, figs. 1-10

Thalassiosira oestrupii var. venrickae G. Fryxell and Hasle Fryxell and Hasle (1980), p. 810, figs. 11-19

Thalassiosira nordenskioeldii Cleve 1873

Cleve (1873), p. 7, pl. 1, fig. 1

Hasle and Syvertsen (1996), p. 56, pl. 5

Thalassiosira symmetrica G. Fryxell and Hasle Fryxell and Hasle (1972), p. 312, figs. 37-46

Thalassiosira trifulta G. Fryxell Fryxell and Hasle (1979), p. 16, figs. 1-24 